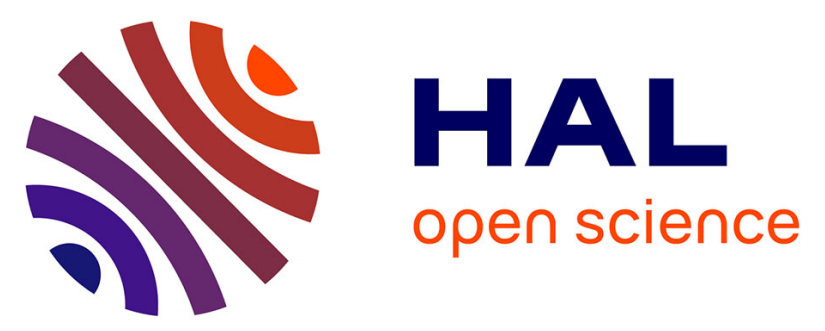

\title{
Corporate social and environmental responsibilities in the Arctic Zone of the Russian Federation: theoretical and methodological approaches
}

Nikolai Bobylev, Sébastien Gadal, Alexander Sergunin, Veli-Pekka Tynkkynen

\section{- To cite this version:}

Nikolai Bobylev, Sébastien Gadal, Alexander Sergunin, Veli-Pekka Tynkkynen. Corporate social and environmental responsibilities in the Arctic Zone of the Russian Federation: theoretical and methodological approaches. Corporate Governance and Innovative Economic Development of the North / , 2021, 1 (1), pp.15-21. 10.34130/2070-4992-20211-1-15. hal-03480714

\author{
HAL Id: hal-03480714 \\ https://hal.science/hal-03480714
}

Submitted on 7 Jan 2022

HAL is a multi-disciplinary open access archive for the deposit and dissemination of scientific research documents, whether they are published or not. The documents may come from teaching and research institutions in France or abroad, or from public or private research centers.
L'archive ouverte pluridisciplinaire HAL, est destinée au dépôt et à la diffusion de documents scientifiques de niveau recherche, publiés ou non, émanant des établissements d'enseignement et de recherche français ou étrangers, des laboratoires publics ou privés.

\section{(ㄷ)(1) $\$$}

Distributed under a Creative Commons Attribution - NonCommerciall 4.0 International 


\title{
СОЦИАЛЬНО-ЭКОНОМИЧЕСКОЕ РАЗВИТИЕ ЭКОНОМИКИ СЕВЕРА SOCIO-ECONOMIC DEVELOPMENT OF THE NORTH ECONOMY
}

\section{Corporate social and environmental responsibilities in the Arctic Zone of the Russian Federation: theoretical and methodological approaches}

\section{Социальная и экологическая ответственность бизнеса в Арктической зоне Российской Федерации: теоретико-методологические подходы}

\author{
DOI: $10.34130 / 2070-4992-2021-1-1-15$ \\ УДК 330.101 .2
}

Н. Г. Бобылёв, Санкт-Петербургский государственный университет (Санкт-Петербург, Россия)

С. Гадаль, Университет Экс-Марсель (Экс-ан-Прованс, Франция)

А. А. Сергунин, Санкт-Петербургский государственный университет (Санкт-Петербург, Россия) и Московский государственный институт международных отношений (Университет) МИД РФ (Москва, Россия)

В.-П. Тюнкюнен, Алексантери-институт, Университет Хельсинки (Хельсинки, Финляндия)

N. G. Bobylev, St Petersburg State University (St Petersburg, Russia)

S. Gadal, Aix-Marseille Université (Aix-en-Provence, France)

A. A. Sergunin, St. Petersburg State University (St Petersburg, Russia) and Moscow State Institute of International Relations (University) of the Ministry of Foreign Affairs of the Russian Federation (Moscow, Russia)

V.-P. Tynkkynen, Aleksanteri Institute, University of Helsinki (Helsinki, Finland)

Основной целью данного исследования является изучение различных теоретических подходов к пониманию природы корпоративной социальной и экологической ответственности в Арктической зоне Российской Федерации (АЗРФ), а также мотивации бизнеса по принятию на себя обязательств в этой сфере.

Методологически исследование опирается на структурно-функциональный и дискурсивный подходы, позволяющие раскрыть внутренние особенности российского и зарубежного дискурса по социальноэкологической ответственности бизнеса в российской Арктике.

Научный вклад данного исследования состоит в том, что в результате проведённой работы выявлена специфика теорий, трактующих корпоративную социальную и экологическую ответственность как форму социального партнёрства или способ совместного распределения выгод (экономическая социология); поведение корпораций в качестве «добропорядочных граждан» общества (социология и политология); часть стратегии управления корпоративными рисками и повышения конкурентоспособности (корпоративный менеджмент) и/или устойчивого развития (экономическое планирование, экология, государственное и муниципальное управление, социальная работа).

Ещё одним существенным результатом (научным вкладом) проведённого исследования стало выделение трёх групп мотивов, которыми руководствуется крупный бизнес в случае принятия на себя социальноэкологических обязательств в АЗРФ: стремление компаний повысить свою привлекательность как бизнеспартнёров, обосновать легитимность своей хозяйственной деятельности в регионе и учесть так называемые политические издержки с тем, чтобы снизить вероятность введения государством некомфортных для компаний норм и правил. 
Полученные результаты могут быть использованы в деятельности подразделений бизнес-структур, ответственных за социальную и природоохранную политику компаний в АЗРФ, а также региональных и муниципальных властей, регулирующих деятельность крупных промышленных и ресурсодобывающих компаний на Крайнем Севере.

Ключевые слова: корпоративная социальная и экологическая ответственность, Арктическая зона Российской Федерации, устойчивое развитие, теория.

The main research objective of this study is to examine various theoretical approaches to understanding the nature of corporate social and environmental responsibility in the Arctic Zone of the Russian Federation (AZRF), as well as the motivation of business to make commitments in this area.

Methodologically, the study is based on the structural-functional and discursive approaches that allow us to reveal the internal features of the Russian and foreign discourses on the social and environmental responsibility of business in the Russian Arctic.

The scientific contribution of this study is that as a result of the work carried out, it reveals the specificity of theories that treat corporate social and environmental responsibility as a form of social partnership or a way of sharing benefits (economic sociology); the behavior of corporations as "good citizens" of society (sociology and political science); part of the strategy of corporate risk management and competitiveness (corporate management) and/or sustainable development (economic planning, ecology, state and municipal management, social work).

Another scientific contribution of this study is that identifies three groups of motives that drive big business in the case of taking on social and environmental obligations in the AZRF: the desire of companies to increase their attractiveness as business partners, to justify the legitimacy of their economic activities in the region and to take into account the so-called political costs in order to reduce the likelihood of the state introducing uncomfortable rules and regulations for companies.

The results obtained can be used in the activities of business units responsible for the social and environmental policy of companies in the Russian Arctic, as well as regional and municipal authorities regulating the activities of large industrial and extractive companies in the Far North.

Keywords: corporate social and environmental responsibility, Arctic Zone of the Russian Federation, sustainable development, theory.

\section{Introduction}

The issue of Corporate Social and Environmental Responsibility (CSER) is attracting increasing attention from business, government, society and academia in Russia. The issue of CSR is of particular relevance to the Arctic Zone of the Russian Federation (ASRF), where economic activities (primarily those of large public and private mining, processing and transport companies) have particularly sensitive consequences for local communities and the fragile environment. The recent environmental disaster at one of Nornickel's thermal power plants in Norilsk has once again highlighted the importance of responsible environmental compliance by big business in this region.

Despite the large number of empirical studies on EE S\&L in the ASRF that have recently appeared in the Russian and foreign scientific literature, many theoretical questions remain unanswered. For example, the question of the applicability of the Western concept of EE S\&L to the conditions of the ASEZ has not been fully explored. It is also unclear how well this concept is interpreted and used by businesses, regulators and academics in relation to the realities of the ASRF. A reading of publications on CSEC in Russia in general and the ASRF in particular gives the impression that there is a great deal of terminological confusion in the current scientific literature. Finally, there is no unified theoretical approach to explaining the CSEC phenomenon itself its nature, reasons for its emergence, specifics of functioning in modern conditions, vector of further development, typology, etc.

This article attempts to analyse two important theoretical issues - the nature of CSEA and the motivation of companies operating in the ASRF themselves to develop CSEA strategies.

\section{Theory and research methodology}

The specificity of this study is that its subject matter is the different theories of BES. In this regard, this study is based on the assumption that modern theories of BES are internally differentiated but integral systems of knowledge about the interaction between business and society, which are characterised by logical dependence of some elements on others, the deductibility of their content from the original basis according to certain logical and methodological principles and rules. The structural components of this knowledge include theories of 
different levels (including paradigmatic), epistemology, research methods and techniques, as well as the totality of theoretical knowledge created within these scientific disciplines.

Each of the social science disciplines studying CSELs has a well-defined "set" of theoretical and methodological guidelines, postulates and research approaches and consists of a number of directions and schools, differing from each other on specific issues while maintaining a worldview unity.

There are two main research approaches used in this research:

The research procedure is to move sequentially from an analysis of more general theoretical ideas about the nature of CSEC to an examination of more specific issues, in particular the motivation of businesses to participate in social and environmental programmes in the ASRF.

1) The structural-functional approach, which is based on understanding the theoretical knowledge of CSELs as a system consisting of elements with specific functions inherent in them, as well as having a structure that develops according to certain laws.

2) Discursive approach aimed at hermeneutic analysis of texts of representatives of various scientific disciplines studying CSELs, including "deciphering" the inner motives of the authors of texts, studying linguistic practices used by researchers in the process of theoretical discourse, identifying "connections" between texts and the presence of interaction/dialogue between them (intertextuality).

The research procedure is to move sequentially from an analysis of more general theoretical ideas about the nature of CSEC to an examination of more specific issues, in particular the motivation of businesses to participate in social and environmental programmes in the ASRF.

\section{Research results \\ The nature of corporate social and environmental responsibility in the Arctic}

Each of the social sciences offers "its own" theoretical approaches to explaining the essence of CSEC. For example, one of the researchers of this problem has counted 37 definitions of this concept [1]. The following theories are the most popular:

In economic sociology, SEA is understood as a form of social partnership that emerges as a response by business to the expectations of society, which believes that companies operating in the ASEZ and deriving substantial benefits from it have certain obligations not only to their employees but also to other people living in the area (including indigenous peoples) and are also responsible for the preservation of the environment that may be affected by these activities [2; 3; 4]. If this partnership does not work, there is a ground for conflict between the companies on the one hand, and the local authorities and society - on the other. In turn, such a conflict is, mostly, unprofitable for business and local actors. The benefits of social partnership are obvious, and therefore companies operating in the ASRF are trying to develop adequate CSR strategies in the region.

A related theory is the theory that considers SEA as a way of benefit/sharing [2; 5; 6]. According to this theory, companies that benefit from their economic activities in a particular territory (in our case, the ASRF) cannot attribute these benefits only to themselves. If they want to continue to operate in this region on a stable basis, they must share the benefits with the local population and take care of improving the comfort of their living environment, including a favourable social and environmental environment.

1. In sociology and political science, the theory of corporations as "good citizens" of society has also become widespread [5; 7]. According to this theory, each social group performs its function in society. For society to develop normally, each social actor (including business) should conscientiously perform its functions. Accordingly, the companies operating in the ASRF are obliged not only to develop the economy of the region, but also to take care of the welfare of the local population and the preservation of the natural wealth of the Russian North.

Modern variants of this theory believe that CSELs are logically derived from corporate ethics, the role of which is increasing in the current environment. According to the proponents of the "ethical approach" to explaining the phenomenon of CSEC, the modern ("civilized") business is not only "chasing clean money", but also understanding that it has certain moral obligations to other members of society $[4 ; 5 ; 8]$.

The theory of the "good citizen" has become especially popular in social sciences due to the fact that in the conditions when there is a global crisis of the state as a source and guarantor of social benefits (the concept of the "welfare state"), someone should take over a part of social functions of the state and ensure progressive development of society [4; 5]. Proponents of this theory believe that modern business is "mature enough" to perform this responsible role. Adherents of this theory, of course, understand that it is not quite applicable to the 
current Russian realities, but they believe that domestic business should strive to achieve high international social, environmental and ethical standards in this area $[2 ; 5 ; 9 ; 6]$.

A number of domestic and foreign researchers believe that the development of high-quality and effective CSR strategies by Russian business is an important tool for reforming Russian socio-economic, political and legal systems based on democratic and market principles $[2 ; 6 ; 9 ; 10 ; 11]$. Companies' assumption of the role of "good citizens" contributes to the elimination of such negative phenomena as corruption, fictitious tenders, "black" and "grey" economy, lack of transparency in corporate and governmental decisions, failure of civil society institutions to participate in the development of these decisions, ignoring the social and environmental aspects of industrial and infrastructure projects in the ASEZs, etc.

2. Within a number of economic sciences (in particular, corporate management), there is a set of theories that explain ESG by business or managerial logic. For example, some researchers suggest that not only the management, shareholders and employees of a company, but also the social environment in which it operates, i.e. local and regional authorities, civil society institutions, particularly vulnerable groups, the media, etc., should be considered a direct and important stakeholder in corporate decision-making. [8; 9; 10; 12]. If the company takes into account the interests of these informal "shareholders", it will improve the quality of its decisions, reduce the likelihood of conflicts with the local population and authorities, and in general, the conditions for the continuation of its business will become more favourable.

A related theory is the theory that considers CCEO as part of the corporate risk management strategy [5; 9]. The more channels a company has to interact with local authorities and communities, the lower the risks associated with the uncertainty of the social and institutional environment, and the more businesses feel safe in this environment.

A similar theory is the one that sees CSE as an integral part of the corporate competitiveness strategy [2; 10; 11]. According to this theory, a company that shows concern for local communities and the environment is more attractive as a partner to all levels of government and other companies and therefore has a better chance of succeeding in obtaining lucrative contracts or promoting its products and services in the ASRF market.

3. Finally, the interdisciplinary concept of sustainable development (sustainable development concept), formally endorsed by international organizations (primarily the UN and its specialized agencies) and national governments, including Russia, offers its own understanding of CSEC. As is known, this concept implies the harmonization of the economic, social and environmental components of development, which, in turn, implies that all social actors are responsible for their actions in these three spheres. From the point of view of this theory, CCEA is seen as the natural responsibility of business to ensure the sustainable development of the ASRF [3; 9; 13]. Similar to entrepreneurs, other participants in Arctic activities (individuals, social groups, institutions, organizations) should also contribute to this goal - to the best of their abilities and capabilities, of course.

\section{Motivation of big business in the field of CSEC}

CSR experts identify three main groups of motives that encourage businesses to take this part of their corporate strategy seriously.

Firstly, these are considerations dictated by the current market conditions, in which companies - primarily their investors and partners - are demanding greater transparency in their work and interaction with the environment in which they operate. The more a company demonstrates its openness and attention to the social and environmental aspects of its activities, the more competitive and less risky it is in local and global markets.

In addition, in today's markets, an adequate level of company transparency and effective CSR strategies are the basis for trust in capital markets and a condition for access to "longer and cheaper" financial resources [10]. Accordingly, CSR disclosure is not an additional duty imposed on businesses, but a tool to enhance the competitiveness and financial stability of companies.

In this regard, many companies operating in "environmentally and socially sensitive" markets, which includes the ASRF, often use voluntary CSR mechanisms and standards as a competitive advantage [10;11].

The best-known voluntary international non-financial reporting standard is the Sustainability Reporting Guidelines developed back in the late 1990s and regularly updated by the non-governmental organization Global Reporting Initiative (GRI) with the participation of representatives of the business, expert and financial communities. The Guidelines include principles, standards and recommendations for the implementation of sustainability reporting. Although not immediately available, Russian companies have begun voluntarily publishing reports using the GRI methodology. For example, the state-owned company "Zarubezhneft" published 
its first GRI-compliant sustainability report in 2013. Since then, this practice has gradually become generally accepted.

Numerous CSER ratings compiled by various non-governmental organisations are intended to help companies operating in the ASEZs to improve their positive image and, consequently, their competitiveness. The first such experience was the environmental rating of oil and gas companies operating in Russia, compiled in 2014 by WWF (World Wildlife Fund) Russia and Creon Consulting Group with the participation of the National Rating Agency [14]. The rating was developed as a tool to assess corporate risks based on an objective comparison and analysis of the environmental responsibility of companies, as well as the quality and maturity of their management. The purpose of the rating was to create a non-governmental mechanism for comparative evaluation of environmental responsibility of companies in the oil and gas sector to stimulate the improvement of efficiency of hydrocarbon resources use, environmental protection and socially responsible business in Russia. The objective of the rating was to obtain objective and comparable information on the level of environmental responsibility of oil and gas companies operating in Russia and the scale of their environmental impact. Such information may be of significant interest to consumers of oil and gas companies' products as well as to investors and lending institutions.

Among the most recent rankings reflecting EE S\&L in the ASRF, it is worth mentioning the "Rating of sustainable development of companies operating in the Russian Arctic", conducted since 2018. Project Office for Arctic Development (PORA) together with the Department of Environmental Economics of the Faculty of Economics of Lomonosov Moscow State University [15]. The ranking reflects the activities of the largest Russian companies of various profiles in the field of EE S\&L in the ASRF quite comprehensively. On the one hand, it demonstrates the desire of large businesses to be as transparent as possible in their work in the northern regions, and, on the other hand, to use this rating to form their positive image and increase their competitiveness in the ASRF market.

The second approach to explaining the motivation for companies to develop their CSEA strategies in the ASRF is based on legitimacy theory, in which the existence of a clear CSEA policy is seen as a way for a company to legitimize its activities in a particular area, obtain a kind of "social license" and remove existing or potential barriers to its activities $[5 ; 6 ; 10]$. In principle, this approach does not deny the importance of market factors in business motivation, because, after all, the legitimation of a company's activities in a particular region also works to increase its competitiveness and reduce market risks.

Finally, the third approach is based on the so-called political cost theory, which considers the assumption by business of voluntary social and environmental obligations as a preventive measure to reduce the likelihood of the introduction of uncomfortable rules and regulations for companies by the state [2; 10]. A number of researchers believe that, in the case of companies' activities in the ASRF, SEA is a legacy of the Soviet era, when the state assigned many social functions to enterprises (many of which played a city-forming role). Nowadays, the state is also unable to cope with the numerous social and environmental problems of the Far North on its own, and therefore seeks to shift some of this burden onto the shoulders of businesses. For this reason, some scholars prefer to call the current strategy of SEA in the ASRF "neopaternalistic": it is still "top-down", the population is perceived as a passive object, rather than an active subject of policy $[5 ; 6 ; 16]$.

\section{Conclusion}

Each of the social science disciplines involved in the study of CSEC in the ASRF offers its own explanatory theories. Based on this research, we can conclude that it is unlikely to be worth pursuing a single, comprehensive theory of EE S\&L. Depending on the scientific discipline within which such research is carried out, a single theory may be more useful, which does not compromise the heuristic value of other theories used in other sciences. At the same time, such research should always aim for a clear theoretical and methodological approach, a coherent conceptual framework, and avoidance of worldview eclecticism.

It should be noted that the results obtained in the course of CSEL research are not only of theoretical but also of practical importance. In particular, they can be used in the activities of business units responsible for the social and environmental policy of companies in the ASRF, as well as regional and municipal authorities regulating the activities of large industrial, resource extraction, transport and other companies in the Far North.

\section{Acknowledgements}

The research was carried out in the framework of projects under the Kone Foundation Fellowship Programme at the Collegium of Advanced Studies, University of Helsinki (2020); ERA.Net RUS Plus/Russian 
Foundation for Basic Research (RFBR) No. 18-55-76003; RFBR and Foundation House of Humanities (France) No. 20-514-22001 and PIRE (US National Science Foundation Grant No. 1545913).

\section{Список литературы}

1. Dahlsrud A. How Corporate Social Responsibility is Defined: An Analysis of 37 Definitions // Corporate Social Responsibility and Environmental Management. 2006. № 15. Pp. 1-13.

2. Дохолян С. Б. Экологическая ответственность нефтегазовых компаний в Арктике // Современные проблемы управления природными ресурсами и развитием социально-экономических систем : материалы XII международной научной конференции. М.: Изд-во Московского ун-та им. С.Ю. Витте, 2016. С. 107-115.

3. Forbes B. C. Equity, Vulnerability and Resilience in Social-Ecological Systems: Contemporary Example from the Russian Arctic // Research in Social Problems and Public Policy. 2008. № 15. Pp. 203-236.

4. Kumpula T., Pajunen A., Kaarlejärvi E. M., Forbes B. C., Stammler F. Land Use and Land Cover Change in Arctic Russia: Ecological and Social Implications of Industrial Development // Global Environmental Change. 2011. Vol. 21. № 2. Pp. 550-562

5. Henry L. A., Nysten-Haarala S., Tulaeva S., Tysiachniouk M. Corporate Social Responsibility and the Oil Industry in the Russian Arctic: Global Norms and Neo-Paternalism // Europe-Asia Studies. 2016. Vol. 68. № 8. Pp. 1340-1368.

6. Tysiachniouk M., Henry L. A., Lamers M., van Tatenhove J. Oil Extraction and Benefit Sharing in an Illiberal Context: The Nenets and Komi-Izhemtsi Indigenous Peoples in the Russian Arctic // Society \& Natural Resources. 2018. Vol. 31. № 5. Pp. 556-579.

7. Matten D., Crane A. Corporate Citizenship: Towards an Extended Theoretical Conceptualization. Nottingham: International Center for Corporate Social Responsibility, 2003.

8. Freeman R. E. Stakeholder Theory of the Modern Corporation. Ed. by T. Donaldson, P. H. Werhane, M. Cording. Ethical Issues in Business. Upper Saddle River, NJ: Prentice Hall, 2004. Pp. 38-49.

9. Tynkkynen V.-P., Hitztaler S. What Do ISO Indicators Tell Us about Corporate Social Responsibility and Sustainability in Cities of the Yamal-Nenets Autonomous Okrug, Russia? Ed. by R. W. Orttung. Urban Sustainability in the Arctic: Measuring Progress in Circumpolar Cities. New York/Oxford: Berghahn Books, 2020.

10. Шварц Е. А., Книжников А. Ю., Пахалов А. М., Шерешева М. Ю. Оценка экологической ответственности нефтегазовых компаний, действующих в России: рейтинговый подход // Вестник Московского университета. Сер. 6. Экономика. 2015. № 5. С. 46-67.

11. Shvarts E., Pakhalov A., Knizhnikov A., Ametistova L. Environmental rating of oil and gas companies in Russia: How assessment affects environmental transparency and performance business // Strategy and the Environment. 2018. November. Pp. $1-16$.

12. Stammler F., Peskov V. Building a "Culture of Dialogue" among Stakeholders in North-West Russian Oil Extraction // Europe-Asia Studies. 2008. Vol. 60. № 5. Pp. 831-849.

13. Конышев В.Н., Сергунин А.А., Субботин С.В. Государственный приоритет - устойчивое развитие Российской Арктики // Национальные интересы: приоритеты и безопасность. 2017. № 3 (348). С. 416-430.

14. Рейтинг экологической ответственности нефтегазовых компаний России. M.: WWF России, Creon, Национальное рейтинговое агентство, 2014.

15. Рейтинг устойчивого развития компаний, работающих в Российской Арктике. М.: Проектный офис развития Арктики, 2018.

16. Kelman I., Loe J., Rowe E. W., Wilson E., Poussenkova N., Nikitina E., Fjærtoft D. B. Local Perceptions of Corporate Social Responsibility for Arctic Petroleum in the Barents Region // Arctic Review on Law and Politics. 2016. Vol. 7. № 2. Pp. 152-178.

\section{References}

1. Dahlsrud A. How Corporate Social Responsibility is Defined: An Analysis of 37 Definitions. Corporate Social Responsibility and Environmental Management, 2006, no. 15, pp. 1-13.

2. Dokholyan S. B. Oil and gas companies' environmental responsibility in the Arctic. Sovremennye problemy upravleniya prirodnymi resursami i razvitiem social'no-ekonomicheskih sistem : materialy XII mezhdunarodnoj nauchnoj konferencii [Modern problems of management of natural resources and socioeconomic systems' development. Proceedings of the XIIth international scientific conference]. Moscow: The S.Y. Vitte Moscow University, 2016, pp. 107-115. (In Russian).

3. Forbes B. C. Equity, Vulnerability and Resilience in Social-Ecological Systems: Contemporary Example from the Russian Arctic. Research in Social Problems and Public Policy, 2008, no. 15, pp. 203-236.

4. Kumpula T., Pajunen A., Kaarlejärvi E. M., Forbes B. C., Stammler F. Land Use and Land Cover Change in Arctic Russia: Ecological and Social Implications of Industrial Development. Global Environmental Change, 2011, Vol. 21, no. 2, pp. 550-562.

5. Henry L. A., Nysten-Haarala S., Tulaeva S., Tysiachniouk M. Corporate Social Responsibility and the Oil Industry in the Russian Arctic: Global Norms and Neo-Paternalism. Europe-Asia Studies, 2016, Vol. 68, no. 8, pp. 1340-1368. 
6. Tysiachniouk M., Henry L. A., Lamers M., van Tatenhove J. Oil Extraction and Benefit Sharing in an Illiberal Context: The Nenets and Komi-Izhemtsi Indigenous Peoples in the Russian Arctic. Society \& Natural Resources, 2018, Vol. 31, no. 5, pp. 556-579.

7. Matten D., Crane A. Corporate Citizenship: Towards an Extended Theoretical Conceptualization. Nottingham: International Center for Corporate Social Responsibility, 2003.

8. Freeman R. E. Stakeholder Theory of the Modern Corporation. Ed. by T. Donaldson, P. H. Werhane, M. Cording. Ethical Issues in Business. Upper Saddle River, NJ: Prentice Hall. 2004, pp. 38—49.

9. Tynkkynen V.-P., Hitztaler S. What Do ISO Indicators Tell Us about Corporate Social Responsibility and Sustainability in Cities of the Yamal-Nenets Autonomous Okrug, Russia? Ed. by R. W. Orttung. Urban Sustainability in the Arctic: Measuring Progress in Circumpolar Cities. New York/Oxford: Berghahn Books, 2020.

10. Shvarts E., Knizhnikov A. Y., Pakhalov A. M., Sheresheva M. Y. Assessment of environmental responsibility of oil and gas companies operating in Russia: the rating approach. Moscow University Bulletin. Series no. 6. Economics, 2015 , no. 5. pp. 46-67. (In Russian).

11. Shvarts E., Pakhalov A., Knizhnikov A., Ametistova L. Environmental rating of oil and gas companies in Russia: How assessment affects environmental transparency and performance business. Strategy and the Environment, 2018 , pp. 1-16.

12. Stammler F., Peskov V. Building a "Culture of Dialogue" among Stakeholders in North-West Russian Oil Extraction. Europe-Asia Studies, 2008, Vol. 60, no. 5, pp. 831-849.

13. Konyshev V. N., Sergunin A. A., Subbotin S. V. The state priority - sustainable development of the Russian Arctic. National Interests: Priority and Security, 2017, no. 3 (348), pp. 416-430. (In Russian).

14. Rejting e'kologicheskoj otvetstvennosti neftegazovy'x kompanij Rossii [Rating of environmental responsibility of Russia's oil and gas companies]. Moscow: The Russian WWF/Creon, 2014. (In Russian).

15. Rejting ustojchivogo razvitiya kompanij, rabotayushhix v Rossijskoj Arktike. [Rating of sustainable development of companies operating in the Russian Arctic]. Moscow: Project Office on the Arctic Development, 2018. (In Russian).

16. Kelman I., Loe J., Rowe E. W., Wilson E., Poussenkova N., Nikitina E., Fjærtoft D. B. Local Perceptions of Corporate Social Responsibility for Arctic Petroleum in the Barents Region. Arctic Review on Law and Politics, 2016, Vol. 7, No. 2, pp. $152-178$.

Для цитирования: Бобылёв Н. Г., Гадаль С., Сергунин А. А., Тюнкюнен В.-П. Социальная и экологическая ответственность бизнеса в Арктической зоне Российской Федерации: теоретикометодологические подходы // Корпоративное управление и инновационное развитие экономики Севера: Вестник Научно-исследовательского центра корпоративного права, управления и венчурного инвестирования Сыктывкарского государственного университета. 2021. T. 1. Вып. 1. C. 15-21. DOI: 10.34130/2070-4992-2021-1-1-15.

For citation: Bobylev N. G., Gadal S., Sergunin A. A., Tynkkynen V.-P. Corporate social and environmental responsibilities in the Arctic Zone of the Russian Federation: theoretical and methodological approaches // Corporate Governance and Innovative Economic Development of the North: Bulletin of the Research Center of Corporate Law, Management and Venture Investment of Syktyvkar State University. 2021. Vol. 1, issue 1. P. 1521. DOI: $10.34130 / 2070-4992-2021-1-1-15$. 